\title{
Gbx2 Is Required for the Migration and Survival of a Subpopulation of Trigeminal Cranial Neural Crest Cells
}

\author{
David A. Roeseler ${ }^{1}$, Lona Strader ${ }^{2}$, Matthew J. Anderson ${ }^{3}\left[\right.$ and Samuel T. Waters ${ }^{2, *}$ \\ 1 MilliporeSigma, St. Louis, MO 63103, USA; david.roeseler@milliporesigma.com \\ 2 Division of Sciences and Mathematics, University of the District of Columbia, Washington, DC 20008, USA; \\ Lstrader824@gmail.com \\ 3 Cancer and Developmental Biology Laboratory, National Cancer Institute, Frederick, MD 21702, USA; \\ andersonmj@mail.nih.gov \\ * Correspondence: samuel.waters@udc.edu
}

Received: 1 November 2020; Accepted: 9 December 2020; Published: 11 December 2020

\begin{abstract}
The development of key structures within the mature vertebrate hindbrain requires the migration of neural crest (NC) cells and motor neurons to their appropriate target sites. Functional analyses in multiple species have revealed a requirement for the transcription factor gastrulation-brain-homeobox 2 (Gbx2) in NC cell migration and positioning of motor neurons in the developing hindbrain. In addition, loss of $G b x 2$ function studies in mutant mouse embryos, $G b x 2^{\text {neo }}$, demonstrate a requirement for $G b \times 2$ for the development of NC-derived sensory neurons and axons constituting the mandibular branch of the trigeminal nerve (CNV). Our recent GBX2 target gene identification study identified multiple genes required for the migration and survival of NC cells (e.g., Robo1, Slit3, Nrp1). In this report, we performed loss-of-function analyses using Gbx2 ${ }^{\text {neo }}$ mutant embryos, to improve our understanding of the molecular and genetic mechanisms regulated by Gbx2 during anterior hindbrain and CNV development. Analysis of Tbx20 expression in the hindbrain of $G b x 2^{\text {neo }}$ homozygotes revealed a severely truncated rhombomere (r)2. Our data also provide evidence demonstrating a requirement for $G b x 2$ in the temporal regulation of Krox20 expression in $\mathrm{r} 3$. Lastly, we show that $G b x 2$ is required for the expression of Nrp1 in a subpopulation of trigeminal NC cells, and correct migration and survival of cranial NC cells that populate the trigeminal ganglion. Taken together, these findings provide additional insight into molecular and genetic mechanisms regulated by $G b x 2$ that underlie NC migration, trigeminal ganglion assembly, and, more broadly, anterior hindbrain development.
\end{abstract}

Keywords: Gbx2; anterior hindbrain; neural crest; trigeminal ganglion; mouse; development

\section{Introduction}

The wide range of phenotypes reported in Gbx2 mutant organisms suggest that Gbx2 contributes to numerous divergent cell types and their derivatives during development [1-4]. The highly motile cranial neural crest (NC) cells are one such cell type that $G b \times 2$ is thought to regulate during vertebrate development [5,6]. Multipotent cranial NC cells delaminate and migrate ventrolaterally from the dorsal neuroepithelium, forming components of the cranial ganglion and craniofacial skeletal structures in the distal branchial arches [7]. Cranial NC cells from the midbrain will innervate the distal region of branchial arch (BA)1 and give rise to components of the upper jaw bones and cartilage, while the anterior hindbrain cranial $\mathrm{NC}$ cell populations innervate the proximal region to form elements of the lower jaw [8]. 
The trigeminal cranial ganglia $(\mathrm{nV})$ contains placodal and cranial NC cell-derived sensory neurons as well as motor neurons originating from the ventral neural tube. Both sensory and motor neurons project their axons into BA1 to innervate muscles in the jaw and facilitate mastication [9]. Accumulating data suggest that enzymes that regulate cellular retinoic acid (RA) levels, an integrative network of transcription factors, and secreted signaling molecules are required for $\mathrm{nV}$ progenitors to acquire and maintain their correct spatial identities. Retinoic acid (RA) plays important roles in vertebrate embryonic development and is indispensable in anteroposterior (A-P) patterning of the central nervous system. In addition, the RA-degrading enzymes, CYP26A1 and CYP26C1, are thought to partially regulate the posteriorizing effects of RA in the anterior hindbrain and play a significant role in the production of migratory cranial NC cells [10].

Loss-of-function studies for several transcription factors expressed in the developing anterior hindbrain in mice (e.g., Hoxa2, Hoxb2, and Krox20) have demonstrated a significant role for these molecules in patterning this region by regulating the spatial molecular identity of transverse developmental units, rhombomeres (r). Hox paralog group 2 genes, Hoxa2 and Hoxb1, function to control the anteroposterior (A-P) and dorsoventral (D-V) patterning of neuronal subtypes in the anterior hindbrain [11,12].

Krox20, encoding a zinc finger transcription factor, is expressed before the occurrence of sharp segmental boundaries in the anterior hindbrain and eventually becomes restricted to and identifies $\mathrm{r} 3$ and $\mathrm{r} 5$. Krox20 expression is seen in $\mathrm{r} 5$ neural crest cells at $\mathrm{E} 8.5$ and begins to downregulate in $\mathrm{r} 3$ at E9.5. [13]. By E10.5, Krox20 expression specifically identifies the $\mathrm{nV}$ and $\mathrm{nVII}$ neural crest-derived boundary cap (BC) cells, demarcating the entry and exit points for the connecting axons from the central nervous systems to the periphery [14,15]. Loss-of-function studies for Krox20 demonstrate that $\mathrm{r} 3$ and $\mathrm{r} 5$ cells mix with and acquire $\mathrm{r} 2$ and $\mathrm{r} 4$ phenotypic characteristics and further exhibit a loss of direct target genes, Hoxa2 and the receptor tyrosine kinase gene, Epha4 [14,16,17]. The loss of odd-numbered rhombomere identity in $\mathrm{Krox}_{2} \mathrm{O}^{-/-}$mutants alters the ensuing gene expression patterns in hindbrain neurons, cranial neurons, and cranial NC derivatives [18].

Most functional studies regarding $G b x 2$ have highlighted its role in defining the midbrain-hindbrain boundary (MHB) organizer and development of the anterior hindbrain. Gene inactivation studies in mice have shown that expression of $G b x 2$ is required to maintain normal patterns of expression of key components of MHB organizer, $F g f 8$ and $W n t 1$, and correct formation of r1-r3 and their derivatives, such as the cerebellum and $\mathrm{nV}[2,19-22]$.

Importantly, loss of $G b x 2$ function in mouse embryos $\left(G b \times 2^{-/-}\right)$results in aberrant NC cell patterning [3,5]. Misexpression studies have demonstrated a requirement for $G b \times 2$ for the correct development of NC-derived structures. During mouse development between E8.5 and E9.5, Gbx2 is expressed in the dorsal anterior hindbrain, corresponding to the location where cranial NC cells originate, and persists throughout the major period of NC migration $[5,19,23]$. Studies in $G b x 2^{-/-}$ mutants have shown a requirement for $G b \times 2$ in NC cell migration. These studies identified defects in migratory cranial NC cells, leading to defects in NC derivatives in the central nervous system and abnormalities in craniofacial and cardiovascular components [2,5,6]. Disruption in Slit/Robo signaling and loss of GBX2 target gene Robo1 expression are thought to partially contribute to perturbations within the migratory $\mathrm{r} 4$ and cardiac NC cell populations and contribute to defects observed with the anterior hindbrain and heart $[5,6]$.

In addition to $G b x 2^{-/-}$, a $G b \times 2$ hypomorph mouse has also been characterized. Mouse embryos homozygous for the hypomorphic allele, $G b \times 2^{\text {neo/neo }}$, only express $6-10 \%$ of wild-type $G b x 2$. As a result, $\mathrm{r} 1$ and $\mathrm{r} 3$ are present while $\mathrm{r} 2$ is significantly reduced in $G b x 2^{\text {neo/neo }}$ mutant embryos. In situ hybridization analyses of $G b x 2^{\text {neo/neo }}$ mice revealed a loss of genes expressed in $\mathrm{r} 2$ from E8.5 to E9.5, including Cyp26c1 and Hoxa2. Disruption of $\mathrm{r} 2$ significantly impacts components derived from this region. These defects include loss of $\mathrm{nV}$ cranial NC-derived sensory neurons, the $\mathrm{nV}$ mandibular branch, and the $\mathrm{nV}$ NC-derived $\mathrm{BC}$ cells connecting the peripheral and central neural circuitry. The reduction of $\mathrm{r} 2$ and the loss of cranial NC cell-derived components in $G b \times 2^{\text {neo/neo }}$ mutant embryos support a 
stringent requirement for Gbx2 in the regulation of migrating cranial NC cells and are thought to contribute to early postnatal death [24].

Since a large portion of the anterior hindbrain, $\mathrm{r} 1-\mathrm{r} 3$, fails to develop in $\mathrm{Gbx} 2^{-/-}$embryos, it makes them inappropriate for analyses of many of the anterior hindbrain abnormalities associated with a loss of $G b x 2$ function. In this study, we utilized $G b x 2^{\text {neo/neo }}$ embryos and loss-of-function analyses to improve our understanding of the molecular and genetic mechanisms regulated by Gbx2 during anterior hindbrain and $\mathrm{nV}$ development. We report a significant reduction in r2-derived motor neurons and misregulation of Krox20 expression in $\mathrm{r} 3$. In addition, we demonstrate a requirement for $G b \times 2$ for $\mathrm{Nrp1}$ expression within a subpopulation of $\mathrm{nV}$ NC-derived cells, cranial NC cell migration, and survival of cranial NC cells. These results provide novel insight into the multiple functions of $G b x 2$ during anterior hindbrain development and expand our understanding for the role of $G b x 2$ in the regulation of migrating cranial NC cells and $\mathrm{nV}$ gangliogenesis.

\section{Materials and Methods}

\subsection{Mice and Genotyping}

Descriptions of mice carrying the allele for $G b x 2^{\text {neo }}$ and the genotyping have been previously presented [2]. Gbx $2^{\text {neo/neo }}$ hypomorphic mice contain all exons (1 and 2). The hypomorphic phenotype is due to the insertion of a $497 \mathrm{bp}$ fragment of a neo-resistance cassette used as a selectable marker in gene-targeting, between exons 1 and 2 [24]. Gbx2 neo/neo hypomorphic mice were maintained on a mixed 129XC57BL/6 background while Gbx $2^{\text {neo/+ }}$ and wild-type mice served as controls.

\subsection{In Situ Hybridization}

Whole-mount in situ hybridization was performed as previously described [25]. In situ fluorescein and digoxigenin-labeled riboprobes were transcribed from pBluescript KS(-) plasmids containing the following cDNA fragments: Nrp1 anti-sense probe was provided by Q. Schwarz. The Sox10 anti-sense probe was provided by A. Chandrasekhar while the constructs were engineered in P. Trainor's lab.

\subsection{Electrophoretic Mobility Shift Assay}

Recombinant GBX2 protein purification and gel shift assays were performed as previously described [5]. Synthesized oligonucleotides were annealed and end-labeled with $\left(\gamma^{-32} \mathrm{P}\right.$ ATP) [5]. For the gel shift assay, $940 \mathrm{pM}$ of labeled probe and $720 \mathrm{nM}$ of GBX2 fusion protein were mixed and incubated with $2 \mathrm{X}$ binding buffer (20 mM Tris-HCL, pH 7.4, $50 \mathrm{mM} \mathrm{KCL}, 1 \mathrm{mM}$ fresh dithiothreitol, $10 \%$ glycerol, $200 \mu \mathrm{g} / \mathrm{mL}$ bovine serum albumin (BSA) and $2.2 \mu \mathrm{g} / \mathrm{mL}$ Poly dI/dC) for $30 \mathrm{~min}$ at $25^{\circ} \mathrm{C}$. The reactions were separated on a $6 \%$ nondenaturing polyacrylamide gel at $300 \mathrm{v}$ at room temperature using a $1.0 \times$ Tris-Glycine running buffer. The sequences for the NRP1 oligonucleotides containing the GBX2 binding sites are as follows:

NRP1-F: 5' aacattccaaaaattatcaaccatttcaggaatacatttcataaaagctagattgagttctgcttgttttttatt 3'

NRP1-R: 5' aataaaaaacaagcagaactcaatctagcttttatgaaatgtattcctgaaatggttgataattttggaatgtt $3^{\prime}$

NRP1-F: mutated 5' aacattccaaaaattatcaagattgagttctgcttgttttttatt $3^{\prime}$

NRP1-R: 5' aataaaaaacaagcagaactcaatcttgataatttttggaatgtt $3^{\prime}$

\subsection{Immunohistochemistry}

Mouse embryos were fixed in $4 \%$ paraformaldehyde for $2 \mathrm{~h}$ at $4{ }^{\circ} \mathrm{C}$ and embryos were subsequently washed three times in $1 \mathrm{X}$ phosphate-buffered saline-diethyl pyrocarbonate (PBS-DEPC). Embryos were incubated in $25 \%$ sucrose overnight and embedded in optimal cutting temperature (O.C.T.) Compound (Tissue-Tek Sakura Finetek USA, Inc., Torrance, USA). Serial transverse $12 \mu \mathrm{m}$ cryosections were dried for $60 \mathrm{~min}$ at room temperature (RT) and were washed in PBST (1X PBS-DEPC and 1\% Triton X-100). Sections were incubated with blocking solution (10\% heat-inactivated lamb serum, $1 \%$ BSA, $2.5 \%$ 
Triton X-100) for $90 \mathrm{~min}$ at RT and incubated with the appropriate primary antibodies overnight at $4{ }^{\circ} \mathrm{C}$ at the given dilutions: mouse anti-AP-2 alpha (1:25; 3B5 DSHB), rabbit anti-cleaved caspase-3 (1:1600; Cell Signaling Technology, Danvers, USA), and rabbit anti-E-cadherin (1:100; 24E10 Cell Signaling Technology, Danvers, USA). The sections were washed three times the following day with PBST and incubated with fluorescently conjugated secondary antibodies at the given dilutions: goat anti-rabbit AlexaFluor 488 and goat anti-mouse Alexafluor 568 (1:500; Invitrogen, Pittsburgh, PA, USA). Stained sections were washed six times in PBST and mounted with Vectashield Mounting Media with 4',6'-diamidino-2-phenylinodole (DAPI) (Vector BioLabs, Malvern, PA, USA).

\subsection{Statistical Analysis}

Statistical differences in Casp3-positive apoptotic cells were assessed using Student's $t$-test (Graphpad Prism software, GraphPad, San Diego, USA). Results are represented as mean \pm SEM, and samples are considered statistically significant by having a value of ${ }^{*} p \leq 0.0002$. $n=3 \mathrm{WT}$ embryos, $n=3 \mathrm{~Gb} \times 2^{\text {neo/neo }}$ embryos.

\subsection{Animal Ethics Statement}

Animal experimentation protocols were reviewed and approved by the University of Missouri IACUC (protocol \#7561).

\section{Results}

\subsection{Loss of Gbx2 Results in an Inability to Suckle and Trigeminal Motor Neuron Defects}

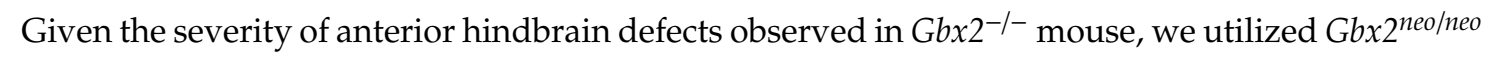
mice to investigate the motor neuron and $\mathrm{NC}$ cell populations that populate $\mathrm{nV}$. As previously reported, analysis of $G b x 2^{\text {neo/neo }}$ mice at P0 revealed that they are born with normal Mendelian frequency [2]. However, further investigation of these mice at $\mathrm{P0}$ revealed a lack of colostrum in the stomachs of Gbx2 $2^{\text {пео/nео }}$ mice compared to controls (Figure 1A,B). The absence of colostrum was observed in $100 \%$ of the $G b x 2^{\text {neo/neo }} \mathrm{P0}$ mice examined $(n=10 / 10)$ and is strongly suggestive of suckling defects in Gbx $2^{\text {nеo/neo }}$ mice.

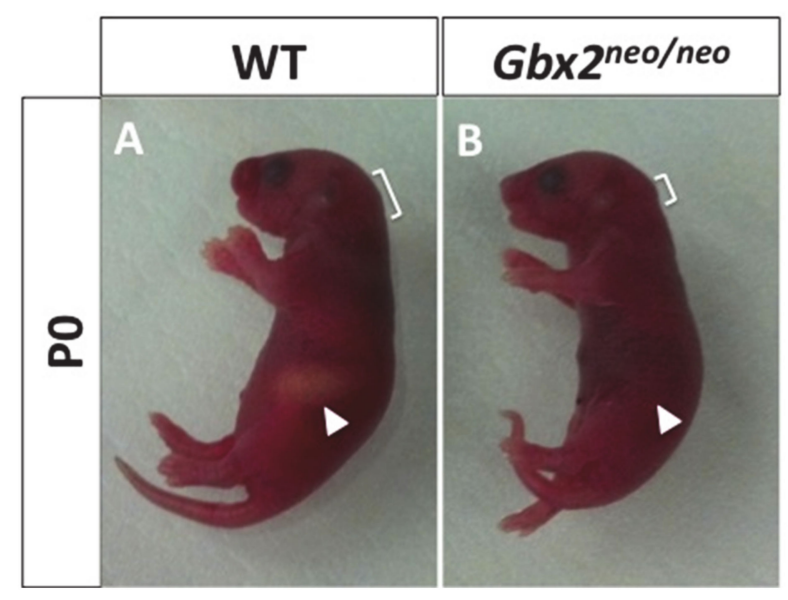

Figure 1. Loss of Gbx2 results in neonatal lethality. Representative photograph of P0 wild-type (A) and $G b x 2^{\text {neo/neo }}$ mice (B). Gbx $2^{\text {neo/neo }}$ lack milk in their stomachs compared to wild-type mice (white arrowhead).

Trigeminal motor neurons of the $\mathrm{nV}$ cranial nerve arise from $\mathrm{r} 2$ and $\mathrm{r} 3$ and subsequently undergo dorsolateral migration from $\mathrm{r} 2$ to form the trigeminal nucleus [26]. Previous investigation of $G b \times 2^{\text {neo/neo }}$ mice revealed a loss of genes expressed in r2 from E8.5 to E9.5, including Cyp26c1 and Hoxa2 [24]. Loss-of-function studies in Hoxa2 ${ }^{-/}$embryos have shown that Hoxa2 is required for maintaining 
the molecular identity of $\mathrm{r} 2$ and $\mathrm{r} 3$ and for the correct motor neuron axon pathfinding from these regions [27]. Since $G b x 2$ is essential for normal $\mathrm{r} 2$ development and Hoxa2 expression is absent in $\mathrm{r} 2$ of $G b x 2^{\text {neo/neo }}$ embryos, we examined the potential impact of reduced $G b x 2$ function on motor neuron cell bodies in the anterior hindbrain. We first analyzed the development of $\mathrm{r} 3$ in $G b \times 2^{\text {neo/neo }}$ embryos using in situ analyses. At E8.5, Krox20 is expressed in r3 and r5 in wild-type embryos (Figure 2A). Our results reveal a decrease in Krox20 expression in the lateral domains of $\mathrm{r} 3$ in Gbx2 ${ }^{\text {neo/neo }}$ embryos when compared to wild-type (Figure 2A,B). Interestingly, these results are consistent with our studies in zebrafish, in which Krox20 expression in r3 is significantly reduced in $g b x 2$ morphants [4].

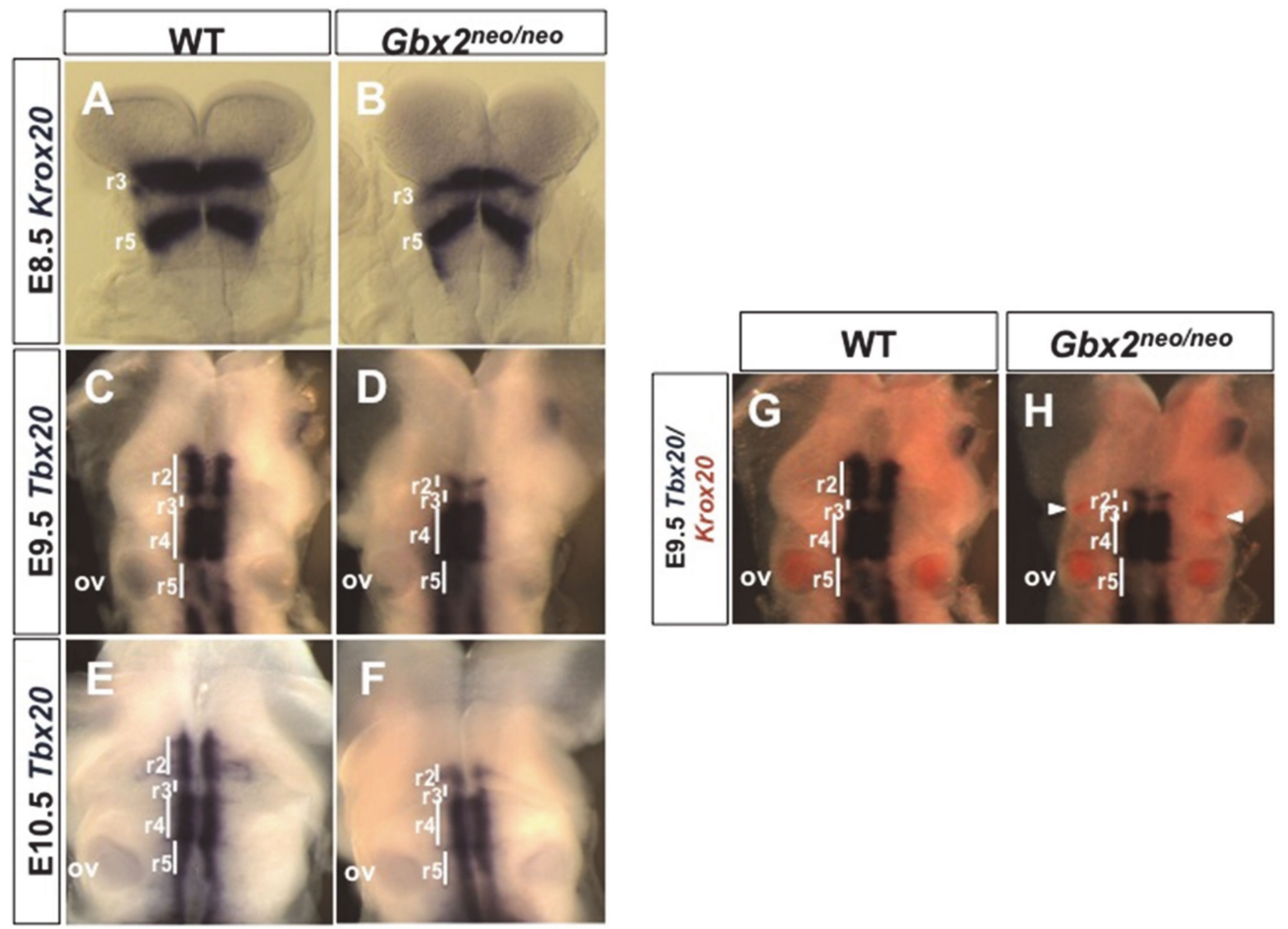

Figure 2. Developmental defects in the trigeminal motor neurons in Gbx2 ${ }^{\text {neo/neo }}$ embryos. Whole and flat-mounted in situ hybridization analyses of Krox20 and Tbx20 in anterior hindbrain at E8.5, and E9.5 and E10.5. Whole-mount preparation (A,B). Dorsal view of Krox20 expression in wild-type (A) and $G b x 2^{\text {пео/nео }}(\mathbf{B})$ embryos at E8.5. (C-F) Flat-mounted hindbrain preparations at E9.5 and E10.5. Dorsal view of Tbx20 expression in the ventral motor columns in wild-type $(\mathbf{C}, \mathbf{E})$ and $G b x 2^{\text {neo/neo }}(\mathbf{D}, \mathbf{F})$ embryos. Tbx20 expression is clearly observed in r2-r5 motor neurons in wild-type controls while Tbx20 expression appears to be significantly reduced in the $\mathrm{r} 2$ motor neurons in Gbx2 ${ }^{\text {neo/neo }}$ embryos at E9.5 and E10.5. (G,H) Flat-mounted hindbrain preparations at E9.5. Krox20 expression is downregulated in r3 at E9.5 in wild-type embryos (G). Ectopic Krox20 expression persist in r3 in Gbx2 ${ }^{\text {neo/neo }}$ embryos (H). $r$, rhombomere; ov, otic vesicle; white bar, represents span of adjacent rhombomere, $r$.

We next used in situ hybridization to analyze the expression of the T-box transcription factor Tbx20. Tbx20 is expressed by branchiomotor neurons in the anterior hindbrain at E9.5 and E10.5 [28]. In wild-type control embryos, Tbx20-expressing motor neurons were observed in their ventral progenitor domain in $\mathrm{r} 2-\mathrm{r} 5$ at E9.5 and were beginning to migrate dorsolaterally from r2 by E10.5 (Figure 2C,E). In contrast to our previous report showing loss of $\mathrm{r} 2$ gene expression in Gbx $2^{\text {neo/neo }}$ embryos [24], we observed a truncated population of Tbx20-expressing motor neurons in $\mathrm{r} 2$ at E9.5 and E10.5 (Figure 2D,F). To further detail our expression analysis, we performed two-color in situ hybridization analyses of Tbx20 and Krox20 in E9.5. Consistent with previous reports [12], we observed a downregulation of Krox20 expression in wild-type embryos at E9.5 (Figure 2G). Surprisingly, our data 
show that ectopic Krox20 expression persists in the dorsal neural tube of $\mathrm{r} 3$ in $G b x 2^{\text {neo/neo }}$ embryos through E9.5 $(n=4 / 4)$ (Figure $2 \mathrm{H})$.

\subsection{Reduction in Gbx2 Results in Trigeminal Cranial NC Cell Defects}

The loss of multiple neural crest-derived structures in the anterior hindbrain of Gbx2 mutant

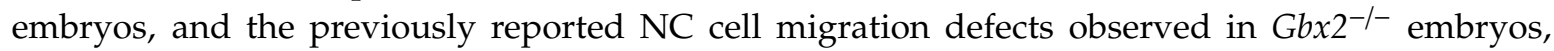

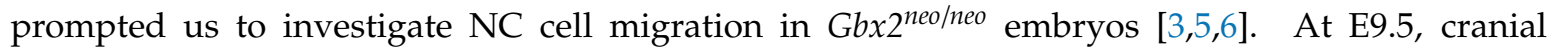
NC cells are observed migrating in distinct streams away from the neuroepithelium at $\mathrm{r} 2$ and $\mathrm{r} 4$, where subpopulations of NC cells will contribute to cranial ganglia, while others will migrate more ventrally into the BAs, giving rise to the bones and cartilage of the face and neck (for review, see [29]). To investigate perturbations in NC cell migration, we used in situ hybridization to analyze Sox10 expression. Sox10 is expressed in migrating NC cells at E9.5, and in NC cell-derived cranial sensory ganglia at E10.5 [30]. In wild-type embryos, we observed NC cells migrating from r2 into BA1 (Figure 3A,C). However, in Gbx2 ${ }^{\text {neo/neo }}$ embryos, we observed a loss of NC cell migration into BA1 and a subpopulation of NC cells residing in the dorsal neuroepithelium (Figure 3B,D). Migration of NC cells from r4 into BA2 did not appear to be affected by the loss of Gbx2 in Gbx2 $2^{\text {neo/neo }}$ embryos.
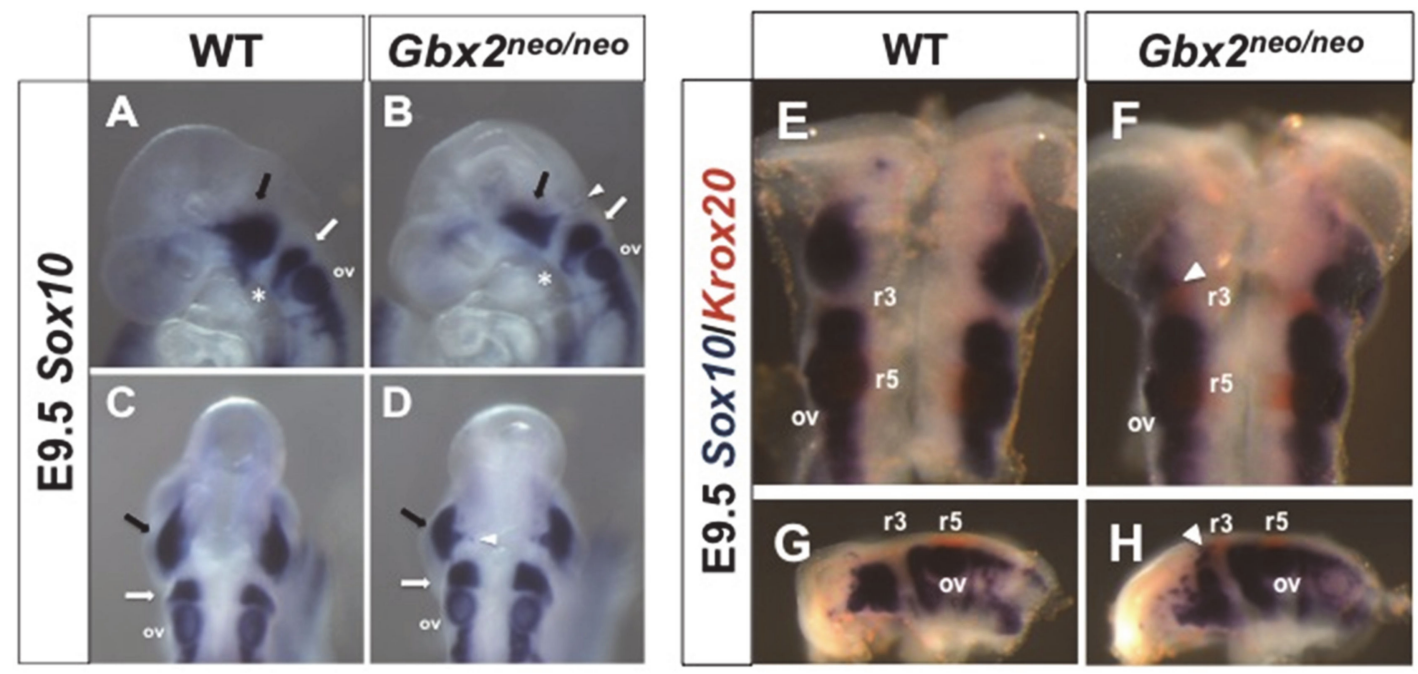

Figure 3. Trigeminal cranial NC cells fail to migrate into BA1 and remain adjacent to the dorsal neural

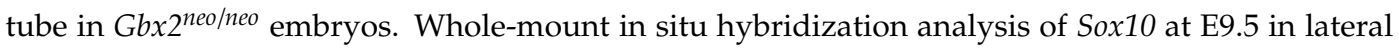
views (A,B) and dorsal views (C,D) demonstrate that trigeminal cranial NC cells fail to migrate into BA1 and remain adjacent to the dorsal neural tube in Gbx2 ${ }^{\text {neo/neo }}$ mutants. Image analysis of Sox10 reveals that trigeminal cranial NC cells in Gbx $2^{\text {neo/neo }}$ embryos fail to migrate into BA1 compared to wild-type controls (A,B). Sox10 is abnormally expressed (white arrowhead) as a lateral stripe (B) and additional punctate expression (D) in the dorsal neural tube within the trigeminal cranial NC cell stream (black arrows) in Gbx $2^{\text {neo/neo }}$ embryos compared to wild-type controls (A,C). Sox10 expression in the hyoid cranial NC cell population (white arrows) and the otic vesicle appears unaffected in Gbx $2^{\text {nеo/neo }}$ mutants. Two-color in situ hybridization analysis of Sox10 and Krox20 on flat-mounted hindbrain preparations in wild-type $(\mathbf{E}, \mathbf{G})$ and $G b x 2^{\text {neo/neo }}(\mathbf{F}, \mathbf{H})$ embryos at E9.5 show that ectopic Krox20-expressing cells observed in Gbx $2^{\text {пеo/neo }}$ mutants are not cranial NC cells. Sox10 expression in dorsal $(\mathbf{E}, \mathbf{F})$ or lateral views $(\mathbf{G}, \mathbf{H})$ is anterior (white arrowhead) to the Krox20 expression in $\mathrm{r} 3$ in Gbx2 $2^{\text {neo/neo }}$ embryos. $r$, rhombomere; ov, otic vesicle; asterisk, BA1.

Loss of Krox20 expression in $\mathrm{r} 3$ and $\mathrm{r} 5$ cells results in their acquisition of even-numbered phenotypic characteristics and subsequent modification of gene expression in the anterior hindbrain and cranial NC cell derivatives [12,18]. We observed persistent ectopic expression of Krox20 in r3 and abnormal migration of a subpopulation of Sox10 expressing NC cells residing in the dorsal neuroepithelium 
of $\mathrm{r} 2$ in E9.5 Gbx2 ${ }^{\text {nеo/neo }}$ embryos (Figure $2 \mathrm{H}$ Figure 3D). Therefore, we examined if ectopic Krox20 expression in $\mathrm{r} 3$ cells may lead to their taking on a similar even-numbered phenotype. We used in situ hybridization to determine if the expression of Krox20 and Sox10 identified the same population of cells in Gbx2 $2^{\text {neo/neo }}$ embryos [31]. Consistent with our results shown in (Figure 2), Krox20 expression persists in $\mathrm{r} 3$ of $G b \times 2^{\text {neo/neo }}$ embryos compared to wild-type at E9.5 (Figure 3E-H); however, we did not observe overlapping expression of Krox20 and Sox10 at the r2/r3 boundary in Gbx2 ${ }^{\text {neo/neo }}$ embryos (Figure 3F,H). Together, these results suggest that migratory cranial NC cells are produced in Gbx2 ${ }^{\text {neo/neo }}$ embryos and that ectopic expression of Krox20-expressing cells located in r3 after E9.0 does not lead to a change in their phenotypic characteristics.

\subsection{Loss of GBX2 Target Gene, Nrp1, Expression in a Subpopulation of Trigeminal Cranial NC Cells in Gbx2 $2^{\text {neoneo }}$ Embryos}

Previous studies have demonstrated that NRP1 is expressed in the $\mathrm{nV}$ ganglion and is required for the correct migration of cranial NC cells [32,33]. Although less severe, the defects in Nrp1 $1^{-/-}$ mutants share similarities to cranial nerve defects observed in Gbx2 mutant embryos, suggesting that Gbx2 may function upstream of Nrp1 in $\mathrm{nV}$ development [3,32]. Interestingly, results from our recent genome-wide ChIP-Seq analysis identified Nrp1 as a top candidate GBX2 target gene, suggesting a possible GBX2-mediated mechanism for $\mathrm{nV}$ ganglion development [5].

To determine if mouse GBX2 protein binds to the GBX2 cis-regulatory NRP1 sequence, we performed an electrophoretic mobility shift assay (EMSA) using recombinant mouse GBX2 and radiolabeled NRP1 oligonucleotides, containing the GBX2-binding sequence. Consistent with results from our GBX2 target identification study, we observed a reduction in the mobility of two shifted complexes in lanes containing full-length GBX2 (Figure 4A, black arrows) [5].

The addition of a GBX2-specific antibody resulted in a supershift, confirming the GBX2/NRP1 interaction, while the addition of only a truncated GBX2 protein, omitting the DNA-binding homeodomain, GBX2 $\Delta \mathrm{HD}$, resulted in a loss of a shifted complex (Figure 4A, lanes 3 and 4 ). In order to demonstrate sequence specificity for GBX2 and the previously identified GBX2-binding site, we used unlabeled NRP1 oligonucleotides, containing the GBX2-binding site at 100×, 300×, and 500× molar concentrations, and observed a progressive reduction in the observed shifted complexes (Figure 4A, lanes 5-7). The observed reduction in shifted complexes was diminished when we added unlabeled truncated NRP1 oligonucleotides, where the GBX2-binding sequence has been omitted (Figure 4A, lanes 8-10). These results demonstrate that GBX2 binds to the previously identified NRP1 target sequence.

We next sought to examine whether Nrp1 expression is affected in migrating trigeminal cranial NC cells in Gbx2 ${ }^{\text {neo/neo }}$ embryos [32,33]. We observed Nrp1 expression in two distinct populations within $\mathrm{r} 2$ and $\mathrm{r} 4$ of wild-type embryos overlapping with the migratory NC cell marker Sox10 at E9.5 (Figure 4B-G). Notably, we observed a marked reduction in Nrp1 expression in the r2 NC cell stream in Gbx2 nеo/nеo embryos, while the expression of Nrp1 in $\mathrm{r} 4$ appeared unaffected by the loss of Gbx2 (Figure 4H-M). Nrp1 expression in r4 at E9.5 is consistent with previous reports [32,34]; however, our observation of Nrp1 expression in $\mathrm{r} 2$ is novel. We also observed weak Nrp1 expression at the MHB (Figure 4B,C,F,G), which is expanded caudally through r1 in Gbx2 $2^{\text {neo/neo }}$ embryos (Figure 4H,I,L,M). Together, these results demonstrate that GBX2 binds to the previously identified NRP1 target sequence and supports the notion that GBX2 directly regulates the expression of Nrp1 in a subpopulation of trigeminal cranial NC cells. 

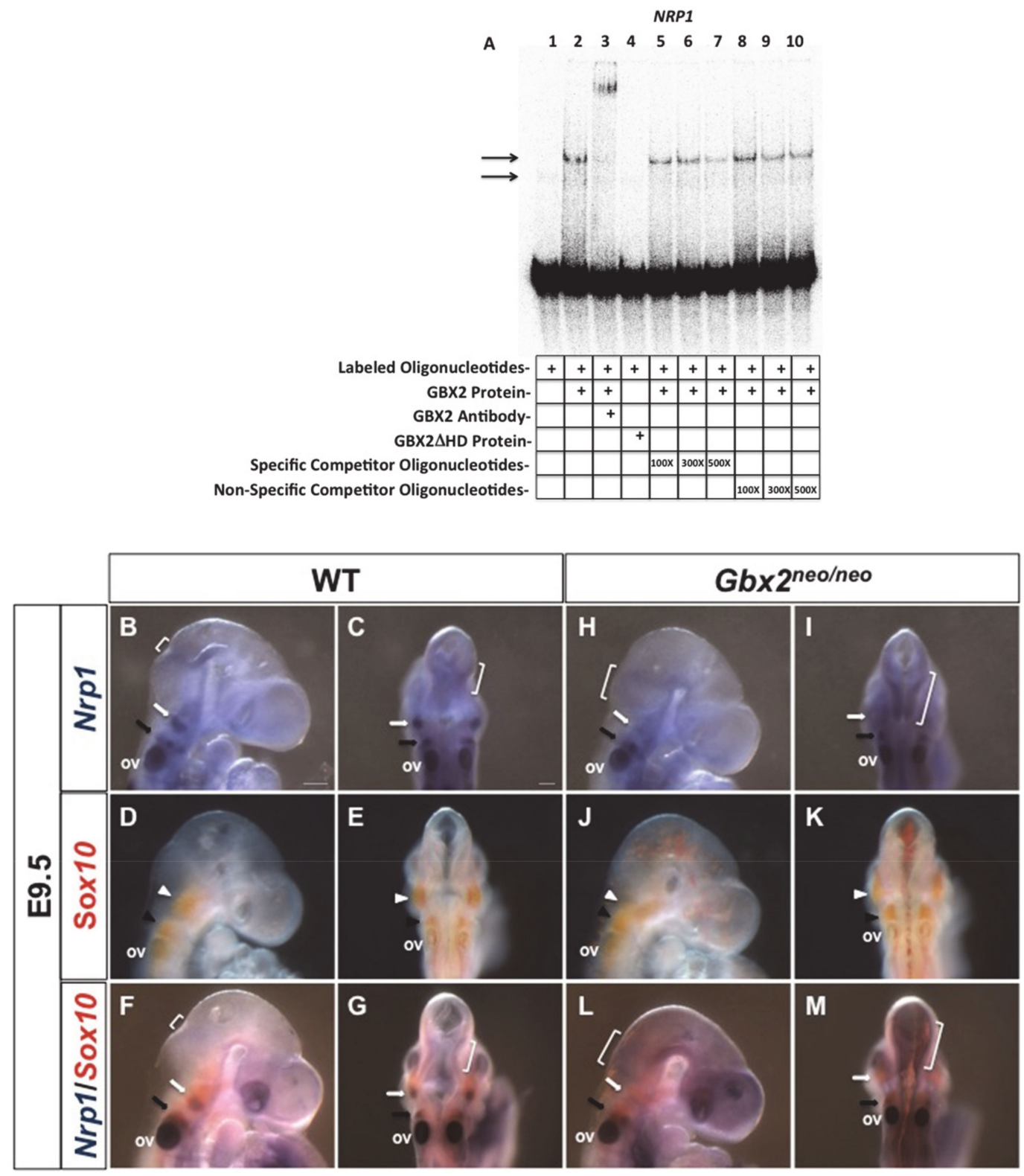

Figure 4. GBX2 binding to NRP1 and loss of Nrp1 in subpopulation of migrating trigeminal cranial NC cells in Gbx2 ${ }^{\text {neo/neo }}$ embryos. (A) Gel-shift analysis for GBX2 target gene, NRP1. A reduction in the mobility of ( $\gamma$-32P) ATP-labeled NRP1 probe is observed with the addition of GBX2 (black arrows, lane 2). A supershift is observed with the addition of a GBX2 antibody (lane 3), whereas no shift is observed with the addition of GBX2 $\triangle \mathrm{HD}$ (lane 4). Addition of unlabeled specific competitor oligonucleotides (lanes 5-7) and 45-mer non-specific competitor oligonucleotides (lanes 8-10), omitting the GBX2 DNA-binding sequence, at $100 \times, 300 \times$, and $500 \times$ molar concentrations. Whole-mount in situ hybridization analysis for $\operatorname{Nrp1}(\mathbf{B}, \mathbf{C}, \mathbf{H}, \mathbf{I})$ and $\operatorname{Sox} 10(\mathbf{D}, \mathbf{E}, \mathbf{J}, \mathbf{K})$ and two-color in situ hybridization $(\mathbf{F}, \mathbf{G})$ in wild-type and $(\mathbf{L}, \mathbf{M})$ in $G b x 2^{\text {nеo/neo }}$ embryos at E9.5. Lateral and dorsal views show Nrp1 expression in two distinct populations of cells (B,C, arrows) corresponding to Sox10 expressing trigeminal (white arrowhead) and hyoid (black arrowhead) cranial NC cells in wild-type embryos $(\mathbf{D}, \mathbf{E})$ and $G b x 2^{\text {neo/neo }}$ mutants $(\mathbf{J}, \mathbf{K})$. Two-color in situ analysis for Nrp1 and Sox10 reveals a reduction in Nrp1 expression within a subpopulation of Sox10-positive trigeminal cranial NC cells in Gbx2 $2^{\text {neo/neo }}$ embryos (compare white arrows in (L) and (M) with (F) and (G)) while Nrp1 expression in the hyoid cranial NC cell stream and the otic vesicle appears unaffected. Brackets indicate ectopic Nrp1 expression throughout $\mathrm{r} 1$ in $G b x 2^{\text {neo/neo }}$ embryos compared to wild-type controls. ov, otic vesicle. 


\subsection{Loss of Gbx2 Results in an Increase in Apoptosis in Migrating Trigeminal NCC}

Loss-of-function studies in zebrafish using an antisense $g b x 2$ morpholino resulted in an increase in cell death in r2, r3, and r5 [4]. The specific loss of $\mathrm{r} 2 \mathrm{NC}$ cell-derived components at E10.5 and the migratory defects observed in the trigeminal stream of NC cells at E9.5 led us to investigate whether an increase in cell death may partially explain the emergent phenotypes. We performed immunohistochemical analyses in the anterior hindbrain of wild-type and Gbx $2^{\text {neo/neo }}$ embryos at E9.5, the stage at which we observed NC cell migratory defects. In wild-type and Gbx $2^{\text {nеo/neo }}$ embryos, we observed AP2 $\alpha$-positive NC cells migrating away from the dorsal neuroepithelium, populating the $\mathrm{nV}$ ganglion and BA1 at E9.5 (Figure 5A,B,G,H).
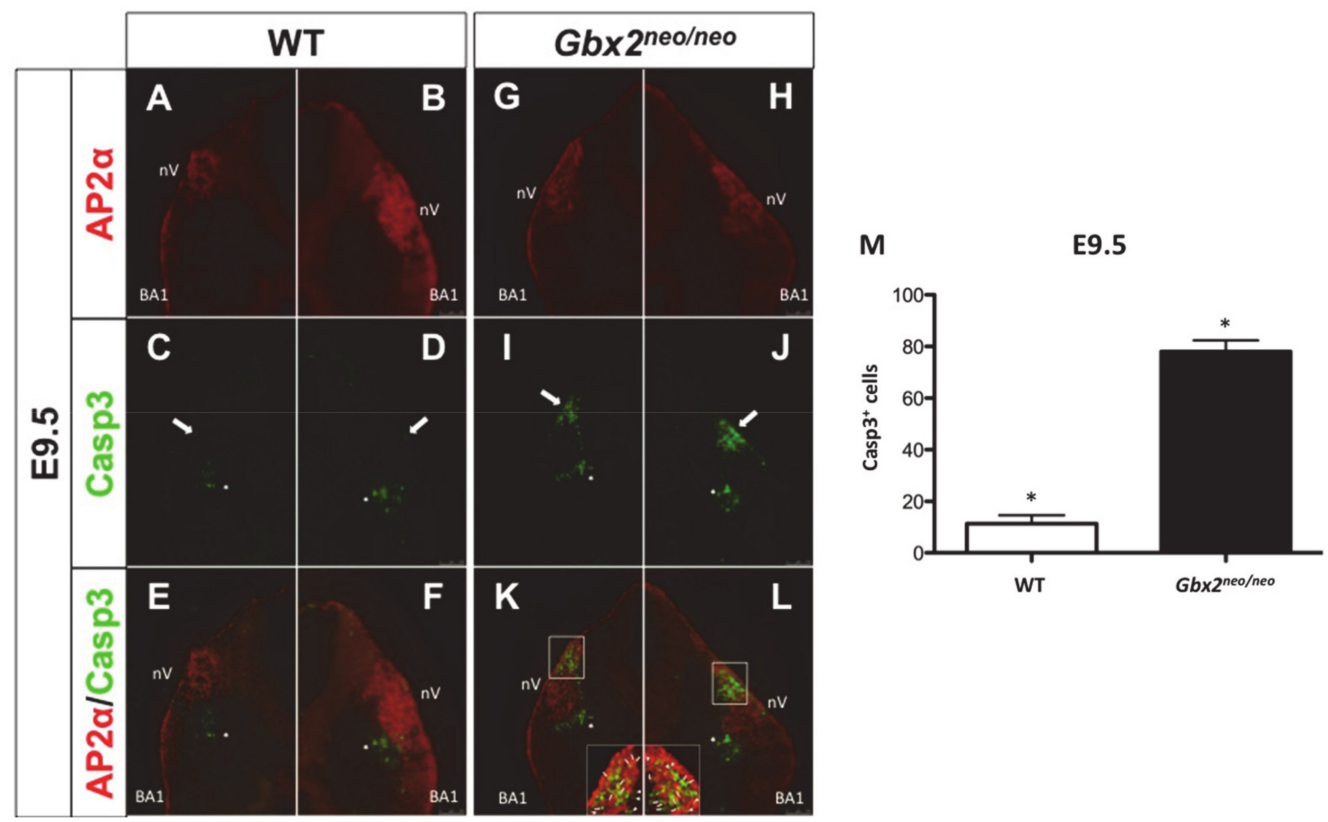

Figure 5. An increase in cell death is observed in Gbx $2^{\text {neo/neo }}$ trigeminal cranial NC cells. (A-L) Immunofluorescence staining of transverse sections through $\mathrm{nV}$ using AP2 $\alpha$ and the apoptotic marker, caspase-3 (Casp3), in E9.5 embryos identified an increase in cell death in cranial NC cells and the surrounding mesenchyme in $G b x 2^{\text {neo/neo }}$ mutants (compare white arrows in $(\mathbf{C}, \mathbf{D})$ to $(\mathbf{I}, \mathbf{J})$. Casp3 positive cells are observed in the mesenchyme medial to $\mathrm{nV}\left({ }^{*}\right)$ in both wild-type $(\mathbf{C}-\mathbf{F})$ and $G b x 2^{\text {neo/neo }}$ embryos (I-L). A dramatic increase in Casp3 positive cells colocalizing with AP2 $\alpha$ in migrating cranial NC cells (inset, white arrows), and an increase in Casp3 in the surrounding mesenchyme (inset, white arrowheads) dorsal of the $\mathrm{nV}$ ganglion, is observed in $G b x 2^{\text {neo/neo }}$ mutants $(\mathbf{K}, \mathbf{L})$ compared to wild-type controls $(\mathbf{E}, \mathbf{F})$. Increase in the number Casp3 positive cells in Gbx2 ${ }^{\text {neo/neo }}$ mutants compared to wild-type controls (M).

We next investigated apoptosis as indicated by activated caspase-3, hypothesizing that an increase in apoptosis in the migratory $\mathrm{r} 2 \mathrm{NC}$ cell stream might contribute to the loss of neural crest-derived structures. Activated caspase- 3 was observed in the mesenchyme in wild-type and $G b x 2^{\text {пео/nео embryos }}$ at E9.5 (Figure 5C,D). However, a significant increase in caspase-3-positive apoptotic cells was observed within the stream of $\mathrm{NC}$ cells migrating into the $\mathrm{nV}$ ganglion and in the surrounding mesenchyme in $G b x 2^{\text {neo/neo }}$ embryos compared to wild-type $(n=5 / 7)$ (Figure 5I,J,M). The range of severity of cell death between $G b x 2^{\text {neo/neo }}$ mutants is consistent with phenotype variability reported in mice containing alternate hypomorphic alleles encoding different genes, such as $F g f 8[35,36]$. Importantly, many of the activated caspase-3-positive cells are colocalized with AP2 $\alpha$-positive migratory NC cells (Figure 5K,L). Thus, an increase in cell death in cranial NC cells may explain the loss of neural crest-derived sensory components of the $\mathrm{nV}$ ganglion. 


\section{Discussion}

In animals, the ability to feed is one of the earliest and most essential behaviors to develop. Our studies of $G b \times 2^{\text {neo/neo }}$ mice suggest that an inability to masticate leads to their premature death at P0. In this study, we have focused our analysis on the development of cranial NC cells and $\mathrm{nV}$, both of which are critical for normal mastication [12].

\subsection{Gbx2 Is a Critical Factor for $n V$ Gangliogenesis}

The initial formation of the $\mathrm{nV}$ ganglion and the establishment of functional neuronal connections with target tissues is largely regulated by the correct spatial-temporal expression of numerous intrinsic transcription factors, secreted signaling and guidance molecules. A combination of motor neurons and placodal and cranial NC cell-derived sensory neurons, originating from divergent populations of cells, migrate from their progenitor domains to form the $\mathrm{nV}$ ganglion. The molecular networks that determine how these divergent populations of motor and sensory neurons precisely acquire their final positions and establish axonal connections with muscles in the jaw remain unclear.

Previous studies have demonstrated a requirement for Gbx2 in positioning the MHB boundary and the juxtaposed positions of Wnt1 and Otx2 in the midbrain and Fgf8 in the anterior hindbrain [2,22]. However, the motor and sensory neurons that comprise the $\mathrm{nV}$ ganglion have not been investigated in detail in Gbx2 mutants. To investigate the role of Gbx2 during $\mathrm{nV}$ gangliogenesis, we analyzed the motor and cranial NC cell populations in Gbx2 $2^{\text {neo/neo }}$ embryos prior to E10.5, when $\mathrm{nV}$ defects are already present. The findings from our study strongly support the idea that the loss of $G b x 2$ and subsequent loss of tissue disrupts $\mathrm{nV}$ motor neuron development and suggest a requirement for $G b x 2$ in regulating the temporal expression of Krox20 in r3. Critically, we provide evidence that Gbx2 is required for regulating the guidance molecule Nrp1 and the correct migration and survival of a subpopulation of cranial NC cells that populate the $\mathrm{nV}$ ganglion.

\subsection{Loss of Gbx2 and Anterior Hindbrain Tissue Disrupts r2 Motor Neuron Development}

Loss-of-function studies in Gbx $2^{\text {neo/neo }}$ mutants have shown a loss of cranial NC cell-derived $\mathrm{nV}$ sensory components; however, it was not determined if the motor neurons in the anterior hindbrain are also affected by the loss of Gbx2. Our analysis of motor neurons in $G b x 2^{\text {neo/neo }}$ mutants revealed a marked reduction in Tbx20 expression in r2. Loss-of-function studies in mice have demonstrated a requirement for $G b x 2$ in positioning the $\mathrm{MHB}$, in part by directly repressing Otx2 expression by competing with class III POU transcription factors for an Otx2 enhancer sequence [37]. Loss of Gbx2 results in a caudal shift of cells within the midbrain lineage at the expense of anterior hindbrain cell types [2,22,38].

Our data suggest that $\mathrm{r}$-derived motor neurons are significantly reduced but not entirely absent in Gbx $2^{\text {neo/neo }}$ mutants at E9.5. This finding is not unexpected given the loss of r2-specific gene expression and loss $\mathrm{r} 2$ of tissue in Gbx $2^{\text {nеo/neo }}$ mutants. Hoxa2 expression is essential for generating trigeminal motor neurons and is absent in $\mathrm{r} 2$ in $G b x 2^{\text {neo/neo }}$ mutants. Further, early patterning defects and the expansion of Fgf8, Wnt1, and Otx2 is observed in Gbx2 ${ }^{\text {neo/neo }}$ embryos prior to E9.5, at the 10 somite stage (ss), which suggests that $\mathrm{r} 2$ cell populations may already be misspecified [24]. Data presented in this study also suggest that the loss of $\mathrm{r} 2$ motor neurons is not due to a defect in cell migration as we observe a loss of $\mathrm{r} 2$ motor neurons at E9.5, prior to the major period of motor neuron cell migration (Figure 2). While we did not observe an increase in cell death, as indicated by activated caspase-3 in the ventral $\mathrm{r} 2 / \mathrm{r} 3$ motor neuron progenitor domains at E9.5, it remains possible that motor neuron cell death may occur slightly earlier in development. It is also possible that there is a more stringent requirement for Gbx2 specifically for $\mathrm{r} 2$ motor neurons, mediating their development through a non-cell-autonomous mechanism. A thorough investigation of a multitude of motor neuron-specific markers may further elucidate the fate of r2 motor neurons; however, such an undertaking lies beyond the scope of this study. 


\subsection{Loss of Gbx2 Alters the Temporal Expression of Krox20 in $r 3$}

While gene expression in $\mathrm{r} 2$ is significantly impacted in Gbx2 $2^{\text {neo/neo }}$ embryos, Krox20 expression in r3 at E9.0 appeared to be intact [24]. Interestingly, results from this study show that ectopic expression of Krox20 is maintained in $\mathrm{r} 3$ of $G b x 2^{\text {neo/neo }}$ mutants at E9.5, when expression is downregulated in wild-type mice. Studies in the chick, rat, and mouse have all demonstrated that Krox20 expression is partially regulated by numerous developmentally important transcription factors. In the mouse, Meis, Hoxb1, and Pbx factors directly activate Krox20 in r3 [39]. Adding to the complexity of regulating Krox20 expression, gain- of and loss-of-function of Pax 6 in the rat hindbrain identified a negative feedback loop via upregulation of the Krox20-repressor gene, Nab1. The network regulating Krox20 through Pax6/Nab1 is downstream of FGF signaling [40].

Fgf8, Fgf17, and FGF target genes, Spry1 and Spry4, expression domains are expanded caudally in Gbx2 ${ }^{\text {neo/neo }}$ embryos [24]. However, evidence from previous studies suggests that they do not directly contribute to the prolonged expression of Krox20 reported in this study. A recent study in zebrafish demonstrated that FGF signaling and Spry4 are primarily required to modulate the timing of the onset of Krox20 expression in r3 and r5 and not maintenance later in development [41]. This is further supported by the fact that the onset of Krox20 expression is not affected in Gbx ${ }^{\text {neo/neo }}$ mutants (Figure 2).

Changes in RA in the anterior hindbrain may also account for alterations in Krox20 expression

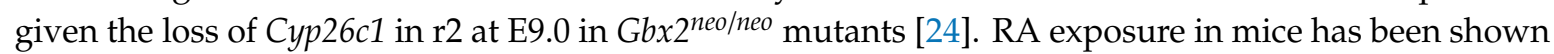
to induce temporal changes in Krox20 expression in r3, where it is initially delayed at E8.5 and appears later at E10.0, altering Hox gene expression and inducing a posterior transformation of r2/r3 [42]. $G b x 2$ is required to mediate the repression of Otx2 by RA as it induces Gbx2 [19]. Furthermore, in Gbx $2^{-1-}$ embryos, removal of the caudally expanded Ot $x 2$ results in the recovery of Krox20 expression in $\mathrm{r} 3$, suggesting that Gbx2 plays a permissive-not instructive_role in $\mathrm{r} 3$ development [19]. In the

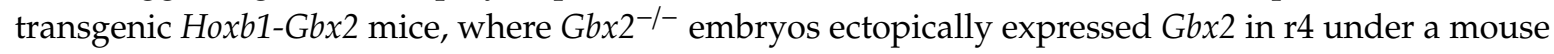
Hoxb1 enhancer, Gbx2 was able to rescue Krox20 expression in r3 [43]. These data support the notion that Gbx2 may partially function non-cell-autonomously during r2/r3 development, in agreement with the suggested functions of $g b x 2$ in zebrafish [4].

Gbx2 expression is primarily localized to $\mathrm{r} 1$ and not $\mathrm{r} 2 / \mathrm{r} 3$ in the anterior hindbrain at E9.5. The data provided in this study, along with previously published results, support a non-cell-autonomous role for Gbx2 in regulating the temporal expression of Krox20 in r3. As Krox20 regulates the patterning of even/odd rhombomeres through both cell-autonomous and non-cell-autonomous mechanisms, the impact of temporally misregulating Krox20 expression in Gbx2 ${ }^{\text {neo/neo }}$ mutants remains to be determined [31].

\subsection{Misregulation of GBX2 Target Gene, Nrp1, in Gbx2 $2^{\text {neo/neo }}$ Mutants}

In vertebrates, neuropilins are transmembrane glycoproteins whose signaling is in part mediated by binding to members of the class 3 semaphorins (SEMA) or the vascular endothelial growth factors (VEGF) [44]. There are two NRP receptors, NRP1 and NRP2, and they mediate VEGF or SEMA signaling through interactions with either VEGF receptors or members of the plexin (PLXN) family of transmembrane glycoproteins, respectively $[45,46]$. Signaling through NRP and PLXN receptors elicits both chemorepulsion- and chemoattraction-mediated responses controlling both soma and axon migration during brain development [47]. The precise combination of signal and receptor proteins is thought to partially determine the repulsive and attractive responses and establish the correct migratory patterning of neuronal cells and their axons [48-50].

We have previously demonstrated that GBX2 directly targets NRP1 in human prostate cancer cells (PC-3). We now show that GBX2 binds to the identified NRP1 target sequence by EMSA and provide in vivo data supporting the notion that $G b x 2$ is required to regulate Nrp1 in the anterior hindbrain and in a subset of trigeminal cranial NC cells (Figure 5) [5]. Beyond the few studies that have investigated the function of Nrp1 signaling in the cerebellum during the late embryonic and early postnatal developmental stages, little data are available describing a role for Nrp1 at the very earliest 
stages of the developing cerebellum primordium at E9.5 [51,52]. However, there is a growing body of knowledge describing the role of Nrp1 during axonal and soma guidance of cranial NC cells.

Overexpression and loss-of-function studies have shown a requirement for NRP1 in neural and heart development [53-55]. In addition, SEMA signaling through NRP and PLXN receptors promotes the correct guidance of cardiac NC cells through the pharyngeal arches [56,57]. In the mouse, SEMA/NRP1 signaling is thought to prevent intermingling of hyoid and trigeminal cranial $\mathrm{NC}$ cell populations during migration [32]. Compound $\mathrm{Nrp1}^{-/-} ; \mathrm{Nrp}^{-/-}$mutants have a more severe phenotype than single mutants, suggesting that these receptors function synergistically to prevent mixing of hyoid and trigeminal cranial NC cell streams [32]. However, a recent study has suggested that Nrp2 does not compensate for Nrp1 in migrating cranial NC cells as siRNA knockdown of Nrp1 in chick r4 leads to a failure of cranial NC cell entry into BA2 while the additional loss of Nrp2 had no observable effect on $\mathrm{r} 4$ cranial NC cell migration [58].

Intriguingly, the trigeminal cranial NC cell migratory defect observed in Gbx2 ${ }^{\text {neo/neo }}$ mutants does not coincide with the cell mixing phenotypes previously reported in $\mathrm{Nrp1}^{-/-}$mouse embryos. An explanation for the differences in phenotypes could be partially explained by the upregulation of Krox20 in r3 and downstream target genes such as Epha4, which has been shown to restrict cell mingling between $\mathrm{r} 2$ and $\mathrm{r} 4$ [17,59]. Furthermore, we did not observe a complete loss of Nrp1 in $G b x 2^{\text {neo/neo }}$ mutants. The tissue-specific transcriptional regulation of Nrp1 may be due to the Nrp1 GBX2 binding sequence being located within an intronic NRP1 sequence, which may therefore function as an enhancer of Nrp1 expression within a subpopulation of cranial NC cells [5], and data presented in this study).

Previous studies have demonstrated that GBX2 interacts with Groucho/Tle co-repressor proteins and functions as both a transcriptional repressor and activator $[5,60,61]$. This purported transcriptional activity of GBX2 is further supported by previous studies demonstrating the importance of transcription factors modulating spatial and temporal gene expression during development and not functioning in an all-or-none response [62,63]. It is likely that a combination of tissue-specific cofactors and the chromatin architecture also account for determining the transcriptional repression or activation of Nrp1 during development. It is also possible that GBX2 regulation of Nrp1 may function later in development during the migration and bundling of the proximal $\mathrm{nV}$ axons of the mandibular branch. However, the loss of the cranial NC cell-derived component of the mandibular branch prevents us from investigating this possibility in $G b x 2^{\text {nеo/neo }}$ embryos. Future studies investigating Nrp1 signaling and the determination of the downstream pathways affected by the loss of Nrp1 in Gbx2 mutants will further elucidate its functional role during $\mathrm{nV}$ development.

\subsection{Gbx2 Is Required for the Migration and Survival of Trigeminal Cranial Neural Crest Cells}

The role of Gbx2 in neural crest cell populations has been demonstrated in studies in multiple species. Studies in chicks have demonstrated that Wnt signaling is necessary for NC cell specification, while studies in Xenopus have provided evidence that Wnt activation and BMP inactivation are critical for inducing NC cells [64,65]. Recent work in Xenopus has identified Gbx2 as being directly activated by Wnt $/ \beta$-catenin signaling, playing an essential role in the neural crest induction pathway [1].

Multiple loss-of-function studies have since demonstrated a requirement for $G b \times 2$ in the migration of cardiac and cranial NC cell populations. Interestingly, we recently identified members of both the Slit/Robo and Nrp/Plxn families of guidance molecules as being direct targets of GBX2. Studies in $G b x 2^{-/-}$mutants have suggested a requirement for Gbx2, Robo1, and Slit2 for cranial NC cell migration into BA4. Similarly, results from this study show that cranial NC cells streaming in BA2 appear disrupted [5,6]. Furthermore, migratory perturbations in the post-otic cranial NC cells of $G b x 2^{-/-}$ mutants are thought to contribute to the numerous pharyngeal arch artery and inner ear phenotypes observed in these mice [3].

Several lines of evidence derived from studies in Gbx $2^{\text {neo/neo }}$ mutants provide additional support to the notion that $G b x 2$ is required for the migration and survival of a subpopulation of trigeminal 
cranial NC cells: (1) the trigeminal cranial NC cell-derived sensory components, the mandibular branch, and the nV BC cells are absent; (2) neural crest EMT appeared intact, while analysis of Sox10 in $G b \times 2^{\text {neo/neo }}$ mutants revealed aberrant trigeminal cranial NC cells migrating from the dorsal neural tube; (3) a loss of GBX2 target and guidance molecule, Nrp1, within the trigeminal crest NC cell stream; and (4) the observed increase in activated caspase- 3 activity in a subpopulation of AP2 $\alpha$-positive trigeminal cranial NC cells and in the surrounding mesenchyme. It is unclear whether $G b x 2$ is required cell-autonomously, non-cell-autonomously, or both, for the normal development of cranial NC cells.

It remains possible that the loss of tissue and multiple r2-specific genes in Gbx $2^{\text {nеo/neo }}$ mutants may contribute to the migratory defects and the increase in cell death observed within the trigeminal cranial NC cell stream. The increase in apoptosis observed within the migrating trigeminal cranial NC cell stream may also account for the loss of Nrp1 expression in migrating NC cells and suggest a possible GBX2-mediated mechanism for $\mathrm{nV}$ development. Interestingly, an anti-apoptotic response from VEGF/NRP1 signaling has been reported in multiple cell types including cancer cells, stem cells, and neurons [66-68]. It is possible that the loss of the migratory factor Nrp1, and the overall mispatterning of the anterior hindbrain, contribute to the migration defects and the increase in the trigeminal cranial NC cell death in Gbx $2^{\text {neo/neo }}$ mutants.

The proposed functions of $G b \times 2$ in the patterning and survival of cranial NC cells and the expression of Krox20 in the anterior hindbrain are similar to those observed with other homeobox-containing transcription factors. Msx 1 and Msx2 have been implicated in the specification of cranial NC cells and are required for their migration and survival. Moreover, $G b x 2, M s x 1$, and $M s x 2$ are required for normal patterning of the anterior hindbrain markers Krox20 and Epha4 [68].

Much of what we know about cranial NC cell migration in the anterior hindbrain in the mouse has come from studies investigating cranial NC cell streaming from $\mathrm{r} 4$ into BA2 and the caudal cardiac streams. However, few studies have attempted to describe the complex interplay between the molecular network of transcription factors and signaling molecules that mediate the migration and survival of the trigeminal cranial NC cells. The results presented in this study further expand our knowledge of $G b x 2$ function within the gene regulatory network underlying migratory cranial $\mathrm{NC}$ cells contributing to $\mathrm{nV}$ and anterior hindbrain development. Figure 6 provides a summary of the morphological and gene expression defects observed in a lateral view of $G b x 2^{-/-}$and $G b x 2^{\text {neo/neo }}$ embryonic mice compared to wild-type embryos at E9.5.

The data from studies in Gbx $2^{\text {neo/neo }}$ mutant embryos revealed ectopic expression of Krox20 in r3, loss of Nrp1 expression in a subset of migrating trigeminal NC cells, and overall reduction of NC cells, likely due to an increase in cell death (Figure 6C). 
A E9.5 Wildtype

B $59.5 \mathrm{~Gb} \times 2^{\prime}$
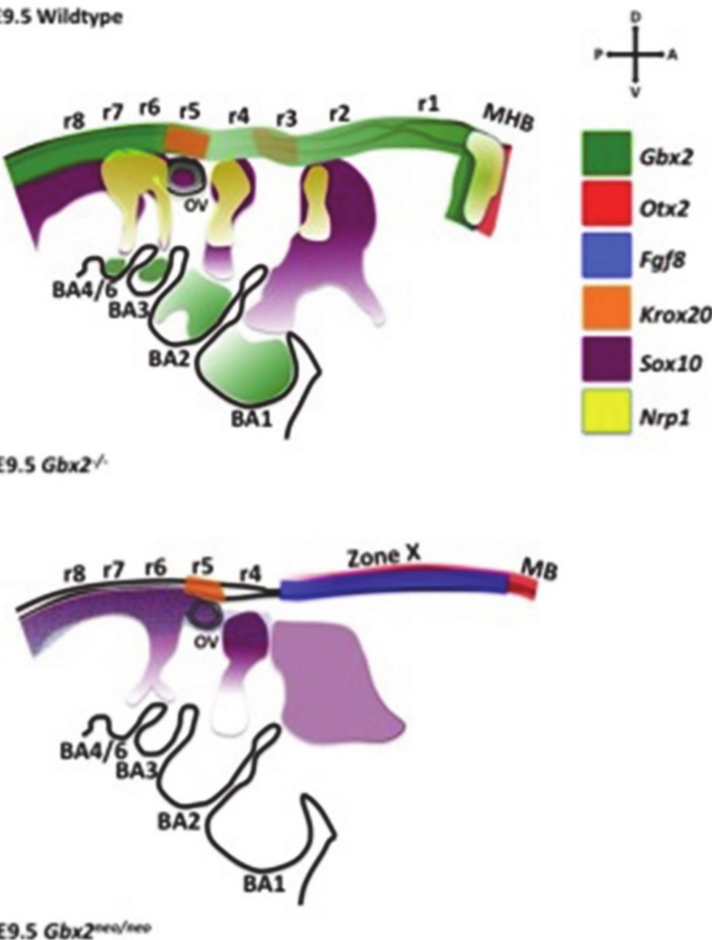

C E9.5 Gbxaren/ene

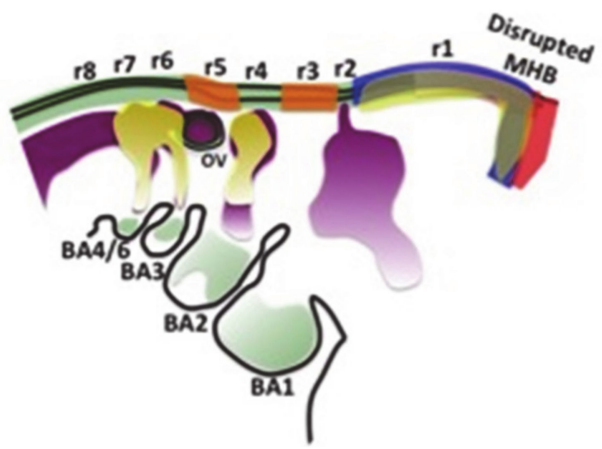

Figure 6. Representation of the morphological and gene expression defects observed in a lateral view of $G b x 2^{-/-}(\mathbf{B})$ and $G b x 2^{\text {neo/neo }}$ embryonic mice (C) compared to wild-type embryos (A) at E9.5. Colored areas represent the gene expression domains as indicated by the key. A loss in color intensity represents a reduction in the expression of the corresponding gene compared to the wild-type embryo. (B) Zone $\mathrm{X}$ indicates the loss of $\mathrm{r} 1-\mathrm{r} 3$ and the abnormal gene expression within the Gbx2-/- embryo. (C) The disrupted MHB in the $G b x 2^{\text {neo/neo }}$ embryos indicates the caudal expansion of gene expression that is normally restricted to this region.

Author Contributions: Conceptualization, S.T.W.; methodology, S.T.W., D.A.R., L.S., M.J.A.; validation, S.T.W., D.A.R.; formal analysis, S.T.W.; resources, S.T.W., M.J.A.; writing—review and editing, S.T.W., D.A.R.; supervision, S.T.W.; project administration, S.T.W.; funding acquisition, S.T.W. All authors have read and agreed to the published version of the manuscript.

Funding: This work has been supported by NSF 1021288 (STW) and NSF 1956450 (STW).

Conflicts of Interest: The authors declare no conflict of interest. The authors declare no conflict of interest with MilliporeSigma, St. Louis, MO 63103, USA The funders had no role in the design of the study, collection or interpretation of the data, or in the preparation of the manuscript. 


\section{References}

1. Li, B.; Kuriyama, S.; Moreno, M.; Mayor, R. The posteriorizing gene Gbx2 is a direct target of Wnt signalling and the earliest factor in neural crest induction. Development 2009, 136, 3267-3278. [CrossRef] [PubMed]

2. Wassarman, K.M.; Lewandoski, M.; Campbell, K.; Joyner, A.L.; Rubenstein, J.L.; Martinez, S.; Martin, G.R. Specification of the anterior hindbrain and establishment of a normal mid/hindbrain organizer is dependent on Gbx2 gene function. Development 1997, 124, 2923-2934. [PubMed]

3. Byrd, N.A.; Meyers, E.N. Loss of Gbx2 results in neural crest cell patterning and pharyngeal arch artery defects in the mouse embryo. Dev. Biol. 2005, 284, 233-245. [CrossRef] [PubMed]

4. Burroughs-Garcia, J.; Sittaramane, V.; Chandrasekhar, A.; Waters, S.T. Evolutionarily conserved function of Gbx2 in anterior hindbrain development. Dev. Dyn. 2011, 240, 828-838. [CrossRef] [PubMed]

5. Roeseler, D.A.; Sachdev, S.; Buckley, D.M.; Joshi, T.; Wu, D.K.; Xu, D.; Hannink, M.; Waters, S.T. Elongation factor 1 alpha1 and genes associated with Usher syndromes are downstream targets of GBX2. PLoS ONE 2012, 7, e47366. [CrossRef] [PubMed]

6. Calmont, A.; Ivins, S.; Van Bueren, K.L.; Papangeli, I.; Kyriakopoulou, V.; Andrews, W.D.; Martin, J.F.; Moon, A.M.; Illingworth, E.A.; Basson, M.A.; et al. Tbx1 controls cardiac neural crest cell migration during arch artery development by regulating Gbx2 expression in the pharyngeal ectoderm. Development 2009, 136, 3173-3183. [CrossRef]

7. Chai, Y.; Jiang, X.; Ito, Y.; Bringas, P., Jr.; Han, J.; Rowitch, D.H.; Soriano, P.; McMahon, A.P.; Sucov, H.M. Fate of the mammalian cranial neural crest during tooth and mandibular morphogenesis. Development 2000, 127, 1671-1679.

8. Kontges, G.; Lumsden, A. Rhombencephalic neural crest segmentation is preserved throughout craniofacial ontogeny. Development 1996, 122, 3229-3242.

9. Serbedzija, G.; Bronner-Fraser, M.; Fraser, S. Vital dye analysis of cranial neural crest cell migration in the mouse embryo. Development 1992, 116, 297-307.

10. Uehara, M.; Yashiro, K.; Mamiya, S.; Nishino, J.; Chambon, P.; Dolle, P.; Sakai, Y. CYP26A1 and CYP26C1 cooperatively regulate anterior-posterior patterning of the developing brain and the production of migratory cranial neural crest cells in the mouse. Dev. Biol. 2007, 302, 399-411. [CrossRef]

11. Davenne, M.; Maconochie, M.K.; Neun, R.; Pattyn, A.; Chambon, P.; Krumlauf, R.; Rijli, F.M. Hoxa2 and Hoxb2 control dorsoventral patterns of neuronal development in the rostral hindbrain. Neuron 1999, 22, 677-691. [CrossRef]

12. De, S.; Turman, J.J. Krox-20 gene expression: Influencing hindbrain-craniofacial developmental interactions. Arch. Histol. Cytol. 2005, 68, 227-234. [CrossRef] [PubMed]

13. Irving, C.; Nieto, M.A.; DasGupta, R.; Charnay, P.; Wilkinson, D.G. Progressive spatial restriction of Sek-1 and Krox-20 gene expression during hindbrain segmentation. Dev. Biol. 1996, 173, 26-38. [CrossRef]

14. Voiculescu, O.; Taillebourg, E.; Pujades, C.; Kress, C.; Buart, S.; Charnay, P.; Schneider-Maunoury, S. Hindbrain patterning: Krox20 couples segmentation and specification of regional identity. Development 2001, 128, 4967-4978. [PubMed]

15. Maro, G.S.; Vermeren, M.; Voiculescu, O.; Melton, L.; Cohen, J.; Charnay, P.; Topilko, P. Neural crest boundary cap cells constitute a source of neuronal and glial cells of the PNS. Nat. Neurosci. 2004, 77, 930-938. [CrossRef]

16. Nonchev, S.; Vesque, C.; Maconochie, M.; Seitanidou, T.; Ariza-McNaughton, L.; Frain, M.; Marshall, H.; Sham, M.H.; Krumlauf, R.; Charnay, P. Segmental expression of Hoxa-2 in the hindbrain is directly regulated by Krox-20. Development 1996, 122, 543-554.

17. Theil, T.; Frain, M.; Gilardi-Hebenstreit, P.; Flenniken, A.; Charnay, P.; Wilkinson, D.G. Segmental expression of the EphA4 (Sek-1) receptor tyrosine kinase in the hindbrain is under direct transcriptional control of Krox-20. Development 1998, 125, 443-452.

18. Levi, G.; Topilko, P.; Schneider-Maunoury, S.; Lasagna, M.; Mantero, S.; Cancedda, R.; Charnay, P. Defective bone formation in Krox-20 mutant mice. Development 1996, 122, 113-120.

19. Li, J.Y.; Joyner, A.L. Otx2 and Gbx2 are required for refinement and not induction of mid-hindbrain gene expression. Development 2001, 128, 4979-4991.

20. Li, J.Y.; Lao, Z.; Joyner, A.L. Changing requirements for Gbx2 in development of the cerebellum and maintenance of the $\mathrm{mid} /$ hindbrain organizer. Neuron 2002, 36, 31-43. [CrossRef] 
21. Li, J.Y.; Lao, Z.; Joyner, A.L. New regulatory interactions and cellular responses in the isthmic organizer region revealed by altering Gbx2 expression. Development 2005, 132, 1971-1981. [CrossRef] [PubMed]

22. Millet, S.; Campbell, K.B.; Epstein, D.J.; Losos, K.; Harris, E.; Joyner, A.L. A role for Gbx2 in repression of Otx2 and positioning the mid/hindbrain organizer. Nature 1999, 401, 161-164. [CrossRef] [PubMed]

23. Bouillet, P.; Chazaud, C.; Oulad-Abdelghani, M.; Dollé, P.; Chambon, P. Sequence and expression pattern of the Stra7 (Gbx-2) homeobox-containing gene induced by retinoic acid in P19 embryonal carcinoma cells. Dev. Dyn. 1995, 204, 372-382. [CrossRef] [PubMed]

24. Waters, S.T.; Lewandoski, M. A threshold requirement for Gbx2 levels in hindbrain development. Development 2006, 133, 1991-2000. [CrossRef] [PubMed]

25. Waters, S.T.; Wilson, C.P.; Lewandoski, M. Cloning and embryonic expression analysis of the mouse Gbx1 gene. Gene Expr. Patterns 2003, 33, 313-317. [CrossRef]

26. Chandrasekhar, A. Turning heads: Development of vertebrate branchiomotor neurons. Dev. Dyn. 2004, 229, 143-161. [CrossRef] [PubMed]

27. Gavalas, A.; Davenne, M.; Lumsden, A.; Chambon, P.; Rijli, F.M. Role of Hoxa-2 in axon pathfinding and rostral hindbrain patterning. Development 1997, 124, 3693-3702.

28. Kraus, F.; Haenig, B.; Kispert, A. Cloning and expression analysis of the mouse T-box gene tbx20. Mech. Dev. 2001, 100, 87-91. [CrossRef]

29. Theveneau, E.; Mayor, R. Neural crest delamination and migration: From epithelium-to-mesenchyme transition to collective cell migration. Dev. Biol. 2012, 366, 34-54. [CrossRef]

30. Dixon, J.; Jones, N.C.; Sandell, L.L.; Jayasinghe, S.M.; Crane, J.; Rey, J.P.; Dixon, M.J.; Trainor, P.A. Tcof1/Treacle is required for neural crest cell formation and proliferation deficiencies that cause craniofacial abnormalities. Proc. Natl. Acad. Sci. USA 2006, 103, 13403-13408. [CrossRef]

31. Giudicelli, F.; Taillebourg, E.; Charnay, P.; Gilardi-Hebenstreit, P. Krox-20 patterns the hindbrain through both cell-autonomous and non-cell-autonomous mechanisms. Genes Dev. 2001, 15, 567-580. [CrossRef] [PubMed]

32. Schwarz, Q.; Vieira, J.M.; Howard, B.; Eickholt, B.J.; Ruhrberg, C. Neuropilin 1 and 2 control cranial gangliogenesis and axon guidance through neural crest cells. Development 2008, 135, 1605-1613. [CrossRef] [PubMed]

33. Fantin, A.; Schwarz, Q.; Davidson, K.; Normando, E.M.; Denti, L.; Ruhrberg, C. The cytoplasmic domain of neuropilin 1 is dispensable for angiogenesis, but promotes the spatial separation of retinal arteries and veins. Development 2011, 138, 4185-4191. [CrossRef] [PubMed]

34. Lumb, R.; Wiszniak, S.; Kabbara, S.; Scherer, M.; Harvey, N.L.; Schwarz, Q. Neuropilins define distinct populations of neural crest cells. Neural Dev. 2014, 9, 1-15. [CrossRef] [PubMed]

35. Meyers, E.N.; Martin, G.R. Differences in left-right axis pathways in mouse and chick: Functions of FGF8 and SHH. Science 1999, 285, 403-406. [CrossRef] [PubMed]

36. Abu-Issa, R.; Smyth, G.; Smoak, I.; Yamamura, K.-I.; Meyers, E.N. Fgf8 is required for pharyngeal arch and cardiovascular development in the mouse. Development 2002, 129, 4613-4625.

37. Inoue, F.; Kurokawa, D.; Takahashi, M.; Aizawa, S. Gbx2 directly restricts Otx2 expression to forebrain and midbrain, competing with class III POU factors. Mol. Cell. Biol. 2012, 32, 2618-2627. [CrossRef]

38. Sunmonu, N.A.; Li, K.; Guo, Q.; Li, J.Y. Gbx2 and Fgf8 are sequentially required for formation of the midbrain-hindbrain compartment boundary. Development 2011, 138, 725-734. [CrossRef]

39. Wassef, M.A.; Chomette, D.; Pouilhe, M.; Stedman, A.; Havis, E.; Desmarquet-Trin Dinh, C.; Schneider-Maunoury, S.; Gilardi-Hebenstreit, P.; Charnay, P.; Ghislain, J. Rostral hindbrain patterning involves the direct activation of a Krox20 transcriptional enhancer by Hox/Pbx and Meis factors. Development 2008, 135, 3369-3378. [CrossRef]

40. Kayam, G.; Kohl, A.; Magen, Z.; Peretz, Y.; Weisinger, K.; Bar, A.; Novikov, O.; Brodski, C.; Sela-Donenfeld, D. A novel role for Pax6 in the segmental organization of the hindbrain. Development 2013, 140, 2190-2202. [CrossRef]

41. Labalette, C.; Bouchoucha, Y.X.; Wassef, M.A.; Gongal, P.A.; Le Men, J.; Becker, T.; Gilardi-Hebenstreit, P.; Charnay, P. Hindbrain patterning requires fine-tuning of early krox20 transcription by Sprouty 4 . Development 2010, 138, 317-326. [CrossRef]

42. Marshall, H.; Nonchev, S.; Sham, M.H.; Muchamore, I.; Lumsden, A.; Krumlauf, R. Retinoic acid alters hindbrain Hox code and induces transformation of rhombomeres 2/3 into a 4/5 identity. Nature 1992, 360, 737-741. [CrossRef] [PubMed] 
43. Vermot, J.; Schuhbaur, B.; Le Mouellic, H.; McCaffery, P.; Garnier, J.-M.; Hentsch, D.; Brûlet, P.; Niederreither, K.; Chambon, P.; Dollé, P.; et al. Retinaldehyde dehydrogenase 2 and Hoxc8 are required in the murine brachial spinal cord for the specification of Lim1+ motoneurons and the correct distribution of Islet1+ motoneurons. Development 2005, 132, 1611-1621. [CrossRef] [PubMed]

44. Gu, C.; Limberg, B.J.; Whitaker, G.B.; Perman, B.; Leahy, D.J.; Rosenbaum, J.S.; Ginty, D.D.; Kolodkin, A.L. Characterization of neuropilin-1 structural features that confer binding to semaphorin $3 \mathrm{~A}$ and vascular endothelial growth factor 165. J. Biol. Chem. 2002, 277, 18069-18076. [CrossRef]

45. Yaron, A.; Huang, P.-H.; Cheng, H.-J.; Tessier-Lavigne, M. Differential requirement for Plexin-A3 and -A4 in mediating responses of sensory and sympathetic neurons to distinct class 3 Semaphorins. Neuron 2005, 45, 513-523. [CrossRef] [PubMed]

46. Soker, S.; Takashima, S.; Miao, H.Q.; Neufeld, G.; Klagsbrun, M. Neuropilin-1 is expressed by endothelial and tumor cells as an isoform-specific receptor for vascular endothelial growth factor. Cell 1998, 92, 735-745. [CrossRef]

47. Chauvet, S.; Cohen, S.; Yoshida, Y.; Fekrane, L.; Livet, J.; Gayet, O.; Segu, L.; Buhot, M.-C.; Jessell, T.M.; Henderson, C.E.; et al. Gating of Sema3E/PlexinD1 signaling by neuropilin-1 switches axonal repulsion to attraction during brain development. Neuron 2007, 56, 807-822. [CrossRef] [PubMed]

48. Kitsukawa, T.; Shimizu, M.; Sanbo, M.; Hirata, T.; Taniguchi, M.; Bekku, Y.; Yagi, T.; Fujisawa, H. Neuropilin-semaphorin III/D-mediated chemorepulsive signals play a crucial role in peripheral nerve projection in mice. Neuron 1997, 19, 995-1005. [CrossRef]

49. Schwarz, Q.; Gu, C.; Fujisawa, H.; Sabelko, K.; Gertsenstein, M.; Nagy, A.; Taniguchi, M.; Kolodkin, A.L.; Ginty, D.D.; Shima, D.T.; et al. Vascular endothelial growth factor controls neuronal migration and cooperates with Sema3A to pattern distinct compartments of the facial nerve. Genes Dev. 2004, 18, 2822-2834. [CrossRef]

50. Taniguchi, M.; Yuasa, S.; Fujisawa, H.; Naruse, I.; Saga, S.; Mishina, M.; Yagi, T. Disruption of semaphorin III/D gene causes severe abnormality in peripheral nerve projection. Neuron 1997, 19, 519-530. [CrossRef]

51. Solowska, J.M.; Mazurek, A.M.; Weinberger, L.; Baird, D.H. Pontocerebellar axon guidance: Neuropilin-1- and semaphorin 3A-sensitivity gradients across basilar pontine nuclei and semaphorin 3A variation across cerebellum. Mol. Cell. Neurosci. 2002, 21, 266-284. [CrossRef] [PubMed]

52. Cioni, J.-M.; Telley, L.; Saywell, V.; Cadilhac, C.; Jourdan, C.; Huber, A.B.; Huang, J.Z.; Jahannault-Talignani, C.; Ango, F.; Huang, J. SEMA3A signaling controls layer-specific interneuron branching in the cerebellum. Curr. Biol. 2013, 23, 850-861. [CrossRef] [PubMed]

53. Kitsukawa, T.; Shimono, A.; Kawakami, A.; Kondoh, H.; Fujisawa, H. Overexpression of a membrane protein, neuropilin, in chimeric mice causes anomalies in the cardiovascular system, nervous system and limbs. Development 1995, 121, 4309-4318.

54. Kawasaki, T.; Kitsukawa, T.; Bekku, Y.; Matsuda, Y.; Sanbo, M.; Yagi, T.; Fujisawa, H. A requirement for neuropilin-1 in embryonic vessel formation. Development 1999, 126, 4895-4902. [PubMed]

55. Giger, R.; Cloutier, J.-F.; Sahay, A.; Prinjha, R.K.; Levengood, D.V.; E Moore, S.; Pickering, S.; Simmons, D.; Rastan, S.; Walsh, F.S.; et al. Neuropilin-2 is required in vivo for selective axon guidance responses to secreted semaphorins. Neuron 2000, 25, 29-41. [CrossRef]

56. Toyofuku, T.; Yoshida, J.; Sugimoto, T.; Yamamoto, M.; Makino, N.; Takamatsu, H.; Takegahara, N.; Suto, F.; Hori, M.; Fujisawa, H.; et al. Repulsive and attractive semaphorins cooperate to direct the navigation of cardiac neural crest cells. Dev. Biol. 2008, 321, 251-262. [CrossRef] [PubMed]

57. Brown, C.B.; Feiner, L.; Lu, M.M.; Li, J.; Ma, X.; Webber, A.L.; Jia, L.; Raper, J.A.; Epstein, J.A. PlexinA2 and semaphorin signaling during cardiac neural crest development. Development 2001, 128, 3071-3080.

58. McLennan, R.; Kulesa, P.M. Neuropilin-1 interacts with the second branchial arch microenvironment to mediate chick neural crest cell dynamics. Dev. Dyn. 2010, 239, 1664-1673. [CrossRef]

59. Xu, Q.; Alldus, G.; Holder, N.; Wilkinson, D.G. Expression of truncated Sek-1 receptor tyrosine kinase disrupts the segmental restriction of gene expression in the Xenopus and zebrafish hindbrain. Development 1995, 121, 4005-4016.

60. Heimbucher, T.; Murko, C.; Bajoghli, B.; Aghaallaei, N.; Huber, A.; Stebegg, R.; Eberhard, D.; Fink, M.; Simeone, A.; Czerny, T. Gbx2 and Otx2 interact with the WD40 domain of Groucho/Tle corepressors. Mol. Cell. Biol. 2007, 27, 340-351. [CrossRef]

61. Schanke, J.T.; Van Ness, B.G. Organization of the transcription factor binding sites in the kappa Ig intron enhancer. Effects of position, orientation, and spacing. J. Immunol. 1994, 153, 4565-4572. [PubMed] 
62. Schanke, J.T.; Marcuzzi, A.; Podzorski, R.P.; Van Ness, B. An AP1 binding site upstream of the kappa immunoglobulin intron enhancer binds inducible factors and contributes to expression. Nucleic Acids Res. 1994, 22, 5425-5432. [CrossRef] [PubMed]

63. LaBonne, C.; Bronner-Frase, M. Neural crest induction in Xenopus: Evidence for a two-signal model. Development 1998, 125, 2403-2414. [PubMed]

64. Garcia-Castro, M.I.; Marcelle, C.; Bronner-Fraser, M. Ectodermal Wnt function as a neural crest inducer. Science 2002, 297, 848-851. [PubMed]

65. Bachelder, R.E.; Crago, A.; Chung, J.; Wendt, M.A.; Shaw, L.M.; Robinson, G.; Mercurio, A.M. Vascular endothelial growth factor is an autocrine survival factor for neuropilin-expressing breast carcinoma cells. Cancer Res. 2001, 61, 5736-5740.

66. Brusselmans, K.; Bono, F.; Collen, D.; Herbert, J.-M.; Carmeliet, P.; Dewerchin, M. A novel role for vascular endothelial growth factor as an autocrine survival factor for embryonic stem cells during hypoxia. J. Biol. Chem. 2005, 280, 3493-3499. [CrossRef]

67. Cariboni, A.; Davidson, K.; Dozio, E.; Memi, F.; Schwarz, Q.; Stossi, F.; Parnavelas, J.G.; Ruhrberg, C. VEGF signalling controls GnRH neuron survival via NRP1 independently of KDR and blood vessels. Development 2011, 138, 3723-3733. [CrossRef]

68. Ishii, M.; Han, J.; Yen, H.-Y.; Sucov, H.M.; Chai, Y.; Maxson, R.E. Combined deficiencies of Msx1 and Msx2 cause impaired patterning and survival of the cranial neural crest. Development 2005, 132, 4937-4950. [CrossRef]

Publisher's Note: MDPI stays neutral with regard to jurisdictional claims in published maps and institutional affiliations.

(C) 2020 by the authors. Licensee MDPI, Basel, Switzerland. This article is an open access article distributed under the terms and conditions of the Creative Commons Attribution (CC BY) license (http://creativecommons.org/licenses/by/4.0/). 